\title{
PERKEMBANGAN DAN PROSPEK SUKUK TINJAUAN TEORITIS
}

\author{
Wiwin Kurniasari \\ Sekolah Tinggi Agama Islam Negeri (STAIN) Salatiga \\ Email:wiwinkurniasari@yahoo.com
}

\begin{abstract}
Abstrak
Sukuk merupakan kesempatan emas bagi individu rakyat Indonesia untuk ikut berpartisipasi menyukseskan pembangunan negara. Untuk masyarakat muslim, ini merupakan instrumen investasi yang sangat aman dan sesuai syariah yang dikeluarkan negara khusus untuk individu rakyat Indonesia. Keuntungan yang diperoleh dapat memberikan penghasilan berupa imbalan atau nisbah bagi hasil yang kompetitif, investor memperoleh imbalan yang lebih tinggi dari rata-rata tingkat bunga deposito bank BUMN. Pembayaran imbalan dan nilai nominal sampai dengan sukuk jatuh tempo dijamin oleh Pemerintah. Imbalan bersifat tetap dan dibayarkan setiap bulan sampai dengan jatuh tempo. Dapat diperjual-belikan di pasar sekunder sesuai dengan harga pasar, sehingga investor berpotensi mendapatkan capital gain di pasar sekunder. Investasi yang aman, karena dijamin oleh UndangUndang. Investasi yang menentramkan, karena tidak bertentangan dengan prinsip-prinsip syariah seperti riba (usury), gharar (uncertainty), dan maysir (gambling). Prosedur pembelian dan penjualan yang mudah dan transparan.
\end{abstract}

Kata kunci : sukuk, obligasi syariah, resiko

\begin{abstract}
Sukuk is a golden opportunity for the people of Indonesia individuals to participate successfully develop the country . For the Muslim community, this is a very safe investment instruments and Shariah compliance issued specifically for the individual countries of the Indonesian people. Benefits can provide income in the form of reward or profit sharing ratio is competitive, investors get a higher return than the average rate of interest on bank
\end{abstract}


deposits and reward BUMN.Value up to sukuk maturity guaranteed by the Government Remuneration is fixed and paid monthly until maturity. Can be traded in the secondary market in accordance with the market price, so investors are likely to get capital gains in the secondarymarket. Investasi safe, because it is guaranteed by the act.investmentsare reassuring, because it does not conflict with Islamic principles such as riba (usury), gharar (uncertainty), and maysir.purchase and sale procedures are easy and transparent .

Keyword: sukuk, shari'ah obligation (Islamic bonds), risk.

\section{Pendahuluan}

Dalam literatur keuangan Islam, istilah Obligasi Syariah lebih dikenal dengan istilah Sukuk. Sukuk berasal dari bahasa Arab "ṣak" (tunggal) dan "ṣukūk" (jamak) yang memiliki arti mirip dengan sertifikat (note). Dalam pemahaman praktisnya, sukuk merupakan bukti (klaim) kepemilikam. Sebuah sukuk mewakili kepentingan, baik penuh maupun proporsional dalam sebuah atau sekumpulan aset. Istilah sukuk sesungguhnya telah dikenal sejak abad pertengahan, di mana umat Islam menggunakan term sukuk dalam konteks perdagangan internasional. Sukuk dipergunakan oleh para pedagang pada masa itu sebagai dokumen yang menunjukkan kewajiban finansial yang timbul dari usaha perdagangan dan aktivitas komersial lainnya. Namun demikian, sejumlah penulis Barat yang memiliki concern terhadap sejarah Islam dan bangsa Arab, menyatakan bahwa șak inilah yang menjadi akar kata "cheque" dalam bahasa latin, yang saat ini telah menjadi sesuatu yang lazim dipergunakan dalam transaksi dunia perbankan kontemporer (Beik, 2011).

The Accounting and Auditing Organisation Of Islamic Financial Institutions (AAOIFI) merupakan organisasi internasional non profit, didirikan di Bahrain pada tanggal 26 Februari 1990, yang menyusun dan menyiapkan standarisasi akuntansi, auditing, goverment ethics, dan kesesuaian berdasarkan prinsip syariah atas produk-produk keuangan syariah. AAOIFI dalam Sharia Standard No.17 menyabutkan bahwa "Investment Sukuk are certificates of equal value representing undivided shares in ownership of tangible assets, usufruct and services or (in the ownership of) the assets or particular 
projects or special investment activity, however, this is true after receipt of the value of the sukuk, the closing of subcription and the employment of funds received for the purpose for which the sukuk were issued." Investasi sukuk adalah sertifikat dengan nilai yang sama yang mewakili bagian kepemilikan yang sepenuhnya terhadap aset/aktiva/kekayaan yang berwujud, manfaat dan jasa atau (kepemilikan dari) aset/aktiva/kekayaan dari suatu proyek atau aktivitas investasi khusus.

Menurut Undang-Undang Nomor 19 Tahun 2008 tentang Sukuk/ Surat Berharga Syariah Negara didefinisikan sebagai surat berharga negara yang diterbitkan berdasarkan prinsip syariah, sebagai bukti atas bagian penyertaan terhadap aset Surat Berharga Syariah Negara, baik dalam mata uang rupiah maupun mata uang asing.

Berdasarkan fatwa Dewan Syariah Nasional MUI DSN-MUI Nomor 32/DSNMUI/IX/2002 sukuk didefinisikan sebagai obligasi syariah, yaitu:

"Surat berharga jangka panjang berdasarkan prinsip syariah yang dikeluarkan emiten kepada pemegang obligasi syariah yang mewajibkan emiten untuk membayar pendapatan kepada pemegang obligasi syariah berupa hasil/margin fee, serta membayar kembali dana obligasi saat jatuh tempo."

Definisi lain Kamal Zubair (2008) dalam penelitiannya menyatakan bahwa sukuk pada prinsipnya mirip seperti obligasi, dengan perbedaan pokok antara lain berupa penggunaan konsep imbalan dan bagi hasil sebagai pengganti bunga, adanya suatu transaksi pendukung (underlying transaction) berupa sejumlah tertentu aset yang menjadi dasar penerbitan, dan adanya akad atau penjanjian antara para pihak yang disusun berdasarkan prinsip-prinsip syariah. Transaksi sukuk bukan akad utang piutang melainkan penyertaan, karena surat hutang menimbulkan kesan adanya bunga yang menurut syariah tidak halal sehingga tidak boleh diterbitkan.

Menurut Nasution, Mustafa Edwin et al. (2006) sukuk atau obligasi syariah adalah "surat berharga sebagai instrumen investasi yang diterbitkan berdasar suau transaksi atau akad syariah yang melandasinya, yang dapat berupa ijarah, mudharabah, musyarakah atau yang lain. 
Undang-undang Nomor 19 yang telah terbit tahun 2008, SBSN diartikan sebagai surat berharga negara yang diterbitkan berdasarkan prinsip syariah, sebagai bukti atas bagian penyertaan terhadap aset SBSN, baik dalam mata uang rupiah maupun valuta asing. Peraturan Menteri Keuangan dinyatakan bahwa Surat Berharga Syariah Negara (SBSN) Ritel atau Sukuk Negara Ritel (SNR) ini adalah SBSN yang dijual kepada individu atau orang perseorangan warga Negara Indonesia melalui agen penjual.

Berdasarkan Bapepam-LK dalam peraturan Nomor IX.A.13 tentang Penerbitan Efek Syariah, sukuk didefinisikan sebagai efek syariah berupa sertifikat atau bukti kepemilikan yang bernilai sama dan mewakili bagian penyertaan yang tidak terpisahkan atau tidak terbagi atas: (1) kepemilikan aset berwujud tertentu; (2) nilai manfaaat dan jasa atas aset proyek tertentu atau aktivitas investasi tertentu; (3) kepemilikan atas aset proyek tertentu atau aktivitas investasi tertentu.

Jika diperbandingkan dengan instrumen konvesional seperti obligasi dan saham, maka sukuk tidak termasuk dalam dua kategori tersebut. Sukuk tidak termasuk saham karena sukuk memiliki umur yang terbatas atau jatuh tempo (maturity). Disamping itu, sukuk bukan merupakan obligasi karena pembagian keuntungan dalam sukuk dilakukan dengan cara bagi hasil atas proporsi penghasilan atau arus kas yang dihasilkan dari aset yang merupakan underlying dalam transaksi sukuk tersebut. Skema bagi hasil semacam ini sangat berbeda dengan obligasi konvensional, terutama dalam kepastian bagi hasil atau bunga yang diperoleh pemilik dana.

\section{Karakteristik Sukuk}

Beberapa karakteristrik sukuk yang menjadi pembeda dengan obligasi konvensional antara lain: (1) merupakan bukti kepemilikan atas aset yang berwujud atau hak bermanfaat; (2) pendapatan dapat berupa imbalan, fee, bagi hasil, atau margin sesuai dengan akad yang dipakai pada penerbitan sukuk; (3) mensyaratkan adanya aset yang mewadahinya (underlying assets); (4) tidak mengandung unsur riba, maisyir, dan gharar; (5) dalam penerbitannya memerlukan peran special purpose vehicle (SPV) yaitu Pemerintah; (6) pembayaran imbalan dan jatuh tempo dijamin oleh 
Undang-undang Nomor 19 Tahun 2008 dan Undang-undang APBN; (7) pembayaran imbalan dilakukan secara bulanan atau semesteran; (8) sukuk dijual dengan harga par, premium, atau diskon; (9) investor sukuk terdiri dari investor syariah \& konvensional, serta investor individual \& institusi; (10) diterbitkan dalam mata uang asing dan rupiah; (11) pada saat jatuh tempo, redemption dapat berupa bullet payment dan periodic amortization over time (diminishing sukuk).

\section{Manfaat Obligasi Syariah (Sukuk)}

Kemampuan penerbitan obligasi syariah (sukuk) dalam mempengaruhi investasi saham ini cukup beralasan melihat nilai manfaat yang terdapat dari penerbitan obligasi syariah (sukuk) ini. Selain itu, potensi penerbitan obligasi syariah (sukuk) ke depan juga diprediksi akan semakin besar. Ali Arsalan Tariq (2004) menjelaskan manfaat obligasi syariah (sukuk) sebagai berikut: "Generally, Sukuk are asset-backed, stable income, tradable and Shari'ah compatible trust certificates. The primary condition of issuance of Sukuk is the existence of assets on the balance sheet of the government, the monetary authority, the corporate body, the banking and financial institution or any entity which wants to mobilize the financial resources. The identification of suitable assets is the first, and arguably most integral, step in the process of issuing Sukuk certificates. Shari'ah considerations dictate that the pool of assets should not solely be comprised of debts from Islamic financial contracts (e.g. Murabaha, Istisna)". Momentum penerbitan obligasi syariah (sukuk) harus menjadi informasi strategis yang berlevel tinggi yang menempatkan isu, tantangan dan peluang Sustainability Development bagi perusahaan dan sektor keuangan, khususnya keuangan Islam. Untuk melihat sejauh mana investor bereaksi terhadap peristiwa tersebut dilakukan pengujian kandungan informasi peristiwa pengumuman atau penerbitan obligasi syariah (sukuk) yang dapat diukur dengan menggunakan tingkat return saham.

\section{Tujuan Penerbitan Obligasi Syariah (Sukuk)}

Tujuan diterbitkannya SBSN adalah untuk membiayai APBN termasuk membiayai pembangunan proyek, mengembangkan pasar keuangan 
syariah, menambah jenis instrument investasi, memanfaatkan barang milik negara, dan memanfaatkan dana masyarakat yang belum terjaring oleh perbankan konvensional. Asset SBSN dapat berupa obyek pembiayaan SBSN ataupun barang milik negara yang memiliki nilai ekonomis. Aset SBSN ini dapat berupa tanah atau bangunan (aktiva berwujud) atau selain tanah dan bangunan (aktiva tidak berwujud) dan aset SBSN ini dijadikan sebagai dasar penerbitan SBSN. Tersedianya aset ini bertujuan untuk menghindarkan unsur riba. Dalam rangka penerbitan SBSN, pemerintah dapat mendirikan perusahaan penerbit SBSN yang biasa disebut dengan Special Purpose Vehicles (SPV) yang berwenang diantaranya untuk menerbitkan SBSN, menjadi agen dalam pelaksanaan transaksi SBSN seperti pembayaran baik imbalan maupun nilai nominal SBSN kepada investor, dan menjadi counterpart Pemerintah dalam transaksi pengalihan aset. Pemerintah dalam hal ini bertanggung jawab atas pembayaran imbalan dan nilai nominal sukuk yang diterbitkan sampai dengan sukuk jatuh tempo.

\section{Jenis-jenis Obligasi Syariah (Sukuk)}

Jenis dari sukuk dapat dikategorikan berdasarkan akad yang mendasari penerbitan sukuk tersebut. Menurut AAOIFI, saat ini, terdapat 9 (sembilan) jenis akad yang dapat digunakan untuk penerbitan sukuk, yaitu: a) Certificates of ownership in leased assets; b) Certificates of ownership of usufructs of existing assets; c) Salam certificates; d) Ishtishna certificates; e) Murabaha certificates; f) Musharaka certificates (participation certificates, mudharaba sukuk; g) investment agency sukuk; h) Muzara'a certificates; i) Musaqa certificates; j) Mugharasa certificates.

Di Indonesia dikenal 4 jenis sukuk yang terdiri dari:

a. Sukuk ijarah yakni sukuk yang berdasarkan akad ijarah di mana satu pihak bertindak sendiri atau dapat diwakili dalam menjual atau menyewakan hak manfaat atas suatu aset kepada pihak lain berdasarkan harga dan periode yang disepakati tanpa diikuti dengan pemindahan kepemilikan aset itu sendiri.

b. Sukuk mudharabah, yakni sukuk yang berdasarkan akad mudharabah di mana satu pihak menyediakan modal dan pihak lain me- 
nyediakan tenaga dan keahlian dan keuntungan dari kerjasama tersebut akan dibagikan berdasarkan perjanjian yang telah disepakati sebelumnya.

c. Sukuk musyarakah, yakni sukuk berdasarkan akah musyarakah di mana dua pihak atau lebih bekerjasama menggabungkan modal untuk membangun proyek baru, mengembangkan proyek yang telah ada, atau membiayai kegiatan usaha. Keuntungan maupun kerugian yang timbul ditanggung bersama sesuai dengan jumlah partisipasi modal masing-masing pihak.

d. Sukuk istisna \& rsquo; yakni sukuk berdasarkan akad istisna \& rsquo; di mana pihak menyepakati jual beli dalam pembiayaan suatu proyek atau barang. Adapun harga, waktu penyerahan, dan spesifikasi barang atau proyek ditentukan terlebih dahulu berdasarkan kesepakatan. Surat Berharga Syariah Negara yang saat ini berlaku menggunakan akad ijarah.

Sementara itu di Indonesia terdapat 2 (dua) jenis akad yang lazim digunakan untuk penerbitan sukuk, yaitu akad ijarah dan mudharabah. Dalam Peraturan Bapepam dan LK No. IX.A.14 tentang Akad-akad yang Digunakan dalam Penerbitan Efek Syariah di Pasar Modal (selanjutnya disebut Peraturan No. IX.A.14) angka 1 a, ijarah didefinisikan sebagai berikut:

"Ijarah adalah perjanjian (akad) di mana Pihak yang memiliki barang atau jasa (pemberi sewa atau pemberi jasa) berjanji kepada penyewa atau pengguna jasa untuk menyerahkan hak penggunaan atau pemanfaatan atas suatu barang dan atau memberikan jasa yang dimiliki pemberi sewa atau pemberi jasa dalam waktu tertentu dengan pembayaran sewa dan atau upah (ujrah), tanpa diikuti dengan beralihnya hak atas pemilikan barang yang menjadi obyek Ijarah."

Dalam akuntansi konvensional, istilah ijarah dapat dipersamakan dengan lease. Ijarah terbagi menjadi 2 (dua) kategori, yaitu ijarah (operating lease) dan ijarah muntahia bittamleek (capital lease). Transaksi ijarah diatur dalam AAOIFI Shari'a Standard No. 8 Ijarah and Ijarah Muntahia Bittamleek. Jenis akad lainnya yang mendasari penerbitan sukuk adalah mudharabah atau muqaradah. Peraturan nomor IX.A.14 mendefinisikan mudharabah sebagai berikut: 
"Mudharabah (qiradh) adalah perjanjian (akad) di mana Pihak yang menyediakan dana (Shahib al-mal) berjanji kepada pengelola usaha (mudharib) untuk menyerahkan modal dan pengelola (mudharib) berjanji untuk mengelola modal tersebut."

Dalam suatu perjanjian mudharabah, keuntungan usaha dibagi menurut kesepakatan kedua belah pihak, sedangkan kerugian yang terjadi merupakan tanggungan penyedia dana, kecuali jika kerugian tersebut terjadi karena kelalaian atau pelanggaran atas kontrak yang dilakukan oleh pengelola dana. Dalam hal ini kerugian harus menjadi tanggungan pengelola dana.

Secara umum, ada dua tipe akad mudharabah, yaitu mudharabah muthlaqah dan mudharabah muqayyadah. Dalam mudharabah muthlaqah (investasi tidak terikat), pemilik modal memberikan wewenang kepada pengelola dana untuk menginvestasikan dananya dalam usaha yang, menurut pertimbangan pengelola dana, layak tanpa memberi batasan semisal tempat, cara maupun jenis usahanya. Dalam kerangka ini, pihak pengelola dana dapat mencampurkan dana pihak pertama, baik dengan dana miliknya sendiri maupun dana pihak lain. Dalam skema mudharabah muqayyadah (investasi terikat), pemilik dana memberikan restriksi dalam pengelolaan dananya, seperti dalam hal tempat, cara dan jenis usaha yang dilakukan. Pembatasan ini bisa termasuk pula pembatasan untuk mencampurkan dana pihak pertama dengan dana-dana dari pihak lain. Selain itu, pemilik dana juga dapat memberi batasan-batasan lain kepada pengelola dana, contohnya larangan kepada pengelola dana untuk melakukan transaksi penjualan yang dibayar dalam bentuk cicilan, atau tanpa jaminan/ penjamin, atau larangan kepada pengelola dana tersebut untuk meneruskan pengelolaan dana kepada pihak ketiga.

\section{Perkembangan Sukuk di Dunia}

Konsep keuangan berbasis syariah Islam dewasa ini telah diterima secara luas di dunia dan telah menjadi alternatif baik bagi pasar yang menghendaki kepatuhan syariah (syariah compliance), maupun bagi pasar konvensional sebagai sumber keuntungan (profit source). Diawali dengan perkembangan yang pesat di negara-negara Timur Tengah dan 
Asia Tenggara, produk keuangan dan investasi berbasis syariah Islam saat ini telah diaplikasikan di pasar-pasar keuangan eropa, Asia, bahkan Amerika Serikat. Selain itu lembaga-lembaga yang menjadi infrastruktur pendukung keuangan Islam. Organisasi global yang telah didirikan seperti The Accounting and Auditing Organisation Of Islamic Financial Institutions (AAOIFI), International Financaial Service Board (IFSB), International Islamic Financial Market (IIFM), dan Islamic Research and Training Institute (IRTI).

Salah satu instrumen keuangan sayriah yang telah diterbitkan baik oleh negara maupun korporasi adalah sukuk atau obligasi syariah. Di beberapa negara, sukuk telah menjadi instrumen pembiayaan anggaran negara yang penting. Pada saat ini, beberapa negara telah menjadi reguler issuer dari sukuk, Malaysia, Bahrain, Brunei Darussalam, Uni Emirate Arab, Qatar, pakistan, dan State of Saxony Anhalt-Jerman. Penerbitan sukuk negara (sovereign sukuk) tersebut biasanya ditujukan untuk keperluan pembiayaan negara secara umum (general funding) atau untuk pembiayaan proyek-proyek tertentu, misalnya pembangunan bendungan, unit pembangkit listrik, pelabuhan, bandar udara, rumah sakit, dan jalan tol. Selain itu sukuk juga dapat digunakan untuk keperluan pembiayaan cash-mismatch, yaitu dengan menggunakan sukuk dengan jangka waktu yang pendek (Islamic Treasury Bills) yang juga dapat digunakan sebagai instrumen pasar uang (Direktorat Kebijakan Pembiayaan Syariah, 2008).

Sejak dirilis pertama kali pada tahun 1990, sukuk terus menunjukkan perannya dalam mendorong pertumbuhan sektor keuangan syariah. Berdasarkan data yang diolah dari database IFIS (Islamic Finance Information Services, 2010), jumlah penerbitan sukuk secara global telah mencapai angka USD 199,18 milyar per Desember 2010, dengan nilai outstanding sukuk sebesar USD 116,84 milyar. Meski sempat mengalami penurunan pada tahun 2008, sebagai akibat dari krisis keuangan dunia, dan juga sebagai dampak dari pernyataan ulama fiqh, Maulana Taqi Usmani, yang menyatakan bahwa 85 persen penerbitan sukuk tidak sesuai syariah, tren penerbitan sukuk pada tahun 2009 mengalami peningkatan yang sangat signifikan. 


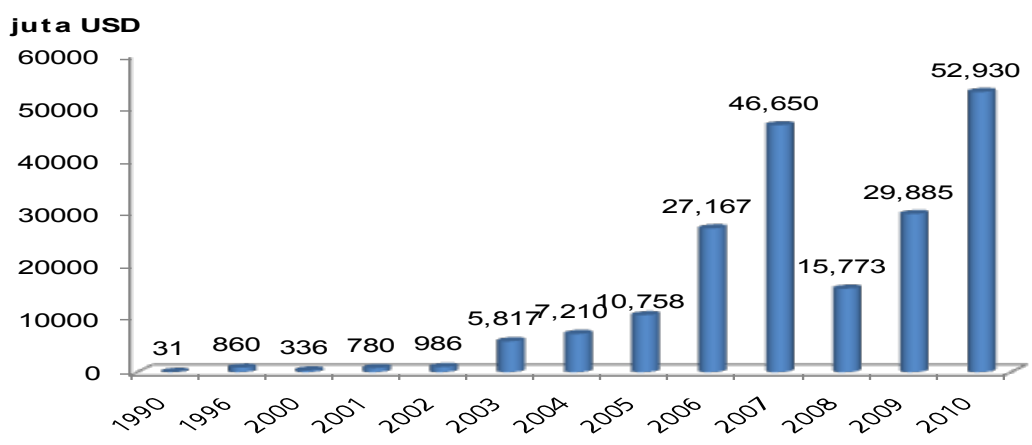

Gambar 1. Total Penerbitan Sukuk Dunia 1990-2010

Sumber : Database IFIS (2010)

Berdasarkan kawasan, database IFIS juga menunjukkan bahwa pasar Asia adalah pasar yang paling banyak memberikan kontribusi. Market share kawasan ini mencapai angka 77 persen, jauh lebih tinggi bila dibandingkan kawasan Timteng yang market share-nya hanya 17 persen. Malaysia masih menjadi negara yang menjadi leading issuer sukuk, dengan market share sebesar 76,37 persen, disusul oleh Pakistan, dengan market share sebesar 6,55 persen. Ini mengisyaratkan bahwa Asia adalah tempat yang sangat menarik bagi investasi syariah, khususnya investasi sukuk.

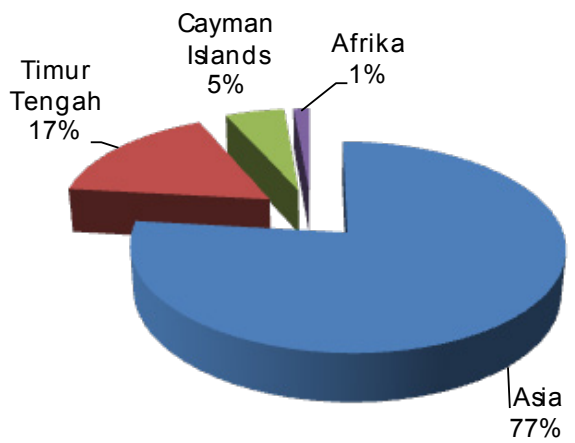

Gambar 2. Penerbitan Sukuk berdasarkan Kawasan

Sumber: Database IFIS (2010)

Sedangkan dari sisi akad, mayoritas sukuk pada tahun 2010 menggunakan akad murabahah (49 persen), disusul oleh akad ijarah (34 persen) dan akad musyarakah (10 persen). Ini menunjukkan bahwa akad-akad berbasis fixed return masih mendominasi penerbitan sukuk. Untuk lebih 
jelasnya, dapat dilihat pada Gambar 3 berikut ini.

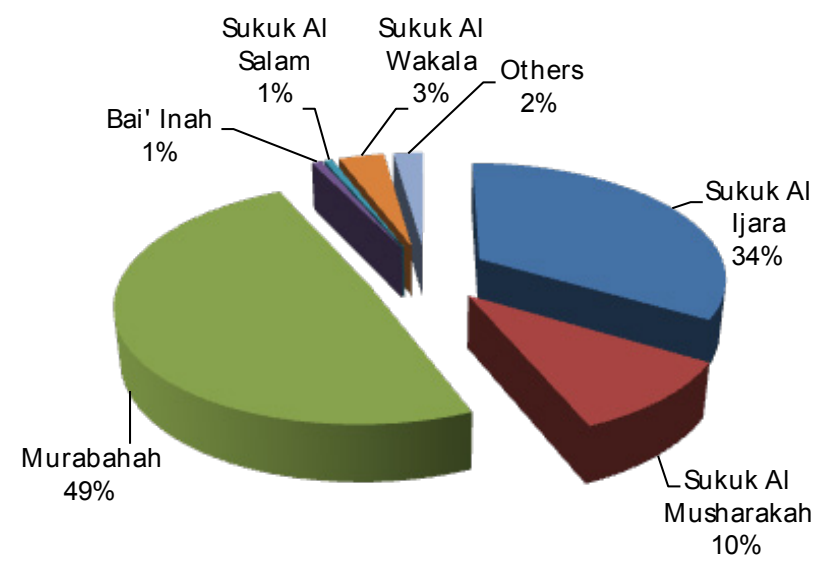

Gambar 3. Penerbitan Sukuk Berdasarkan Akad

Sumber : Database IFIS (2010)

\section{Pertumbuhan dan Perkembangan Sukuk Di Indonesia}

Sementara itu di Indonesia, sukuk pertama yang muncul di pasar adalah sukuk korporasi yang diterbitkan oleh PT Indosat Tbk, yaitu OS Mudharabah Indosat. Sukuk ini diterbitkan pada tanggal 30 Oktober 2002 dengan nilai emisi sebesar Rp 175 milyar dan memiliki masa tenor selama kurang lebih lima tahun. Hingga akhir Desember 2010, berdasarkan Laporan Perkembangan Perbankan Syariah (LPPS) 2010 yang diterbitkan Bank Indonesia, sukuk yang telah diterbitkan mencapai angka 47 buah, dengan nilai total emisi secara kumulatif pada tahun 2010 mencapai angka Rp 7,81 trilyun. Dari angka ini, sebanyak Rp 1,69 trilyun telah dilunasi, sehingga nilai sukuk yang masih beredar dan belum jatuh tempo mencapai angka Rp 6,12 trilyun.

Khusus mengenai sukuk negara, atau dalam bahasa undangundang disebut sebagai SBSN (Surat Berharga Syariah Negara), pertumbuhannya juga sangat pesat. Sejak disahkannya UU No 19/2008 tentang Surat Berharga Syariah Negara, pemerintah telah menerbitkan sukuk negara senilai Rp 47,08 trilyun (hingga 20 Januari 2011), dengan rincian Rp 31,61 trilyun adalah sukuk negara yang diperdagangkan, dan Rp 
15,47 trilyun adalah sukuk negara yang tidak diperdagangkan (Bapepam LK, 2011). Ini menunjukkan bahwa peran sukuk bagi pemerintah menjadi semakin penting seiring dengan perjalanan waktu, terutama sebagai sumber pembiayaan alternatif bagi APBN.

Dalam rangka perluasan basis investor, diversifikasi sumber pembiayaan, dan perkembangan pasar keuangan dalam negeri, Pemerintah Indonesia menerbitkan surat berharga berdasarkan prinsip syariah, atau dikenal secara internasional dengan istilah Sukuk. Instrumen keuangan ini pada prinsipnya sama seperti surat berharga konvensional, dengan perbedaan pokok antara lain berupa penggunaan konsep imbalan dan bagi hasil sebagai pengganti bunga, adanya suatu transaksi pendukung (underlying assets) berupa sejumlah tertentu aset yang menjadi dasar penerbitan sukuk, serta adanya akad atau perjanjian antara para pihak berdasarkan prinsip-prinsip syariah. Untuk keperluan penerbitan surat berharga berdasarkan prinsip syariah, perlu adanya pengaturan secara khusus, baik yang menyangkut instrumen maupun perangkat yang diperlukan. Hal tersebut juga dengan mempertimbangkan adanya kendalakendala yang dihadapi dari sisi legal dalam hal Pemerintah menerbitkan surat berharga berdasarkan prinsip syariah dengan menggunakan basis hukum yang ada di Indonesia pada saat ini. Oleh karena itu pada tanggal 7 Mei 2008 telah disahkan Undang-undang Nomor 19 tahun 2008 tentang Surat Berharga Syariah Negara (SBSN) yang diajukan oleh Pemerintah melaui Dewan Perwakilan Rakyat. Secara garis besar UU tersebut mengatur hal-hal sebagai berikut:

a. Transaparansi pengelolaan Surat Berharga Syariah Negara dalam kerangka kebijakan fiskal dan kebijakan pengembangan pasar Surat Berharga Syariah Negara dengan mengatur lebih lanjut tujuan penerbitannya dan jenis-jenis akad atau perjanjian yang digunakan;

b. Kewenangan Pemerintah untuk menerbitkan Surat Berharga Syariah Negara baik dilakukan secara langsung oleh Pemerintah yang didelegasikan kepada Menteri, ataupun, dilaksanakan melalui perusahaan penerbit yang dibentuk oleh Menteri;

c. Kewenangan Pemerintah untuk menggunakan Barang Milik Negara sebagai dasar penerbitan Surat Berharga Syariah Negara; 
d. Kewenangan wali amanat untuk bertindak mewakili kepentingan Pemegang Surat Berharga Syariah Negara;

e. Kewenangan Pemerintah untuk membayar semua kewajiban yang timbul dari penerbitan Surat Berharga Syariah Negara, baik yang diterbitkan secara langsung oleh Pemerintah maupun melalui Perusahaan Penerbit, secara penuh dan tepat waktu sampai berakhirnya kewajiban tersebut.

f. Landasan hukum bagi pengaturan lebih lanjut atas tata cara dan mekanisme penerbitan Surat Berharga Syariah Negara di pasar perdana maupun perdagangan Surat Berharga Syariah Negara di pasar sekunder agar pemodal memperoleh kepastian untuk memiliki da memperdagangkan Surat Berharga Syariah Negara secara mudah dan aman.

Terminologi Umum UU Surat Berharga Syariah Negara (SBSN):

a. SBSN atau Sukuk Negara

Surat berharga negara yang diterbitkan berdasarkan prinsip syariah, sebagai bukti atas bagian penyertaan terhadap aset SBSN, baik dalam mata uang Rupiah maupun Valuta Asing.

b. Imbalan:

Pembayaran yang dapat berupa sewa,bagi hasil atau margin, atau bentuk pembayaran lainnya sesuai dengan akad penerbitan SBSN, yang diberikan kepada pemegang SBSN sampai dengan berakhirnya periode SBSN.

c. Aset SBSN:

Objek pembiayaan SBSN dan/atau barang milik negara yang memiliki nilai ekonomis, berupa tanah dan/atau bangunan maupun selain tanah dan/atau bangunan,yang dalam rangka penerbitan SBSN dijadikan sebagai dasar penerbitan SBSN.

d. Wali Amanat:

Pihak yang bertindak untuk mewakili kepentingan pemegang SBSN.

e. Hak manfaat: 
Hak untuk memiliki dan mendapatkan hak penuh atas pemanfaatan suatu aset tanpa perlu dilakukan pendaftaran atas kepemilikan dan hak tersebut.

f. Perusahaan Penerbit SBSN:

Badan hukum yang didirikan berdasarkan ketentuan UU ini untuk melaksanakan kegiatan penerbitan SBSN.

Perpajakan Terkait Surat Berharga Syariah Negara (SBSN):

Berikut ini adalah gambaran struktur Surat Berharga Syariah Negara yang ada di Indonesia:

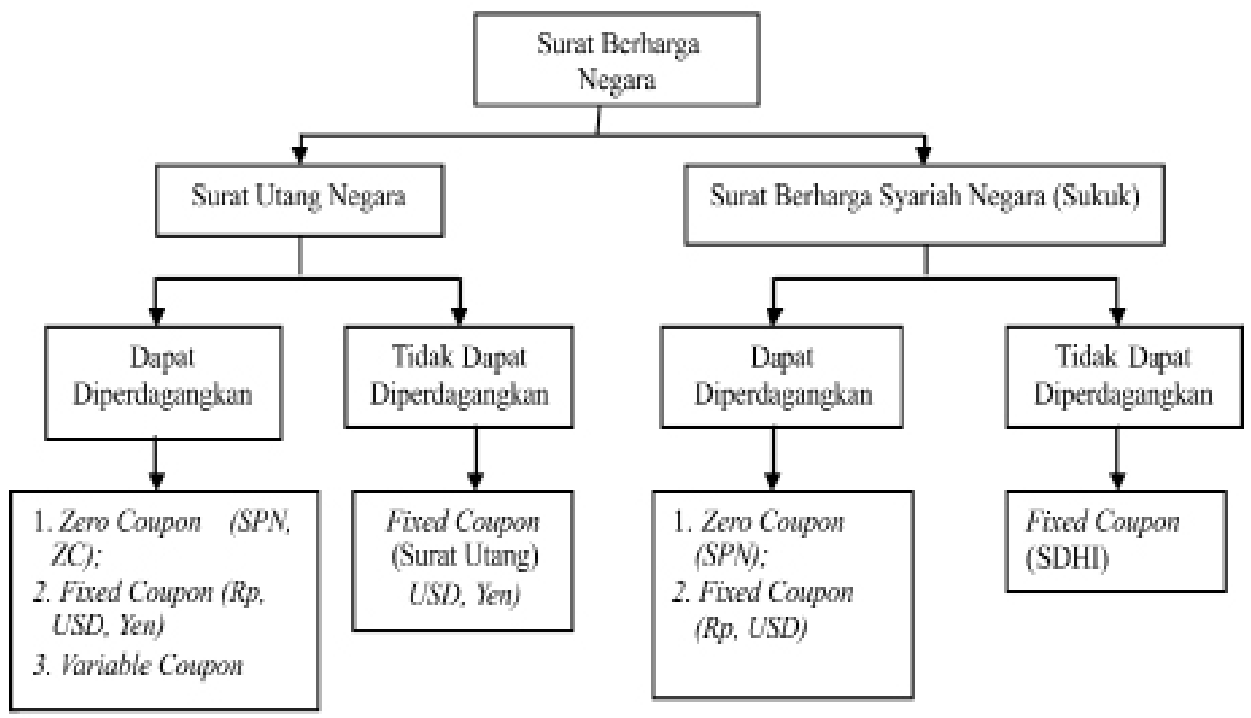

Sumber : Laporan Keuangan Pemerintah Pusat, 2011

Di Indonesia, sukuk korporasi lebih dikenal dengan istilah obligasi syariah. Pada tahun 2002 Dewan Syariah Nasional mengeluarkan fatwa No:32/ DSN-MUI/IX/2002, tentang Obligasi Syariah. Sebagai tindak lanjut atas fatwa di atas, pada Oktober 2002 PT Indosat Tbk. mengeluarkan obligasi syariah yang pertama kali di pasar modal Indonesia dengan tingkat imbal hasil 16,75\%, imbal hasil ini cukup tinggi dibanding rata-rata return 
obligasi konvensional. Pada akhir tahun 2008, sedikitnya telah ada 23 perusahaan yang telah menerbitkan obligasi syariah di Indonesia. Emiten penerbit obligasi Syariah tersebut berasal dari beragam jenis usaha, mulai dari perusahaan telekomunikasi, perkebunan, transportasi, lembaga keuangan, properti, sampai industri wisata.

Walaupun dipandang sangat potensial dan prospektif, perkembangan obligasi syariah di Indonesia dapat dikategorikan sangat terlambat. Total emisi hingga pertengahan 2008 baru mencapai lima trilyun Rupiah lebih (\$500 juta). Dibandingkan dengan Malaysia yang pada pertengahan 2007 saja telah membukukan total emisi RM 111,5 miliar (\$33 miliar). Menuruat Achsien (2004), banyak tantangan yang dihadapi dalam pengembangan obligasi syariah di Indonesia, diantaranya adalah sosialisasi kepada investor, opportunity cost, aspek likuiditas, sampai regulasi atau perundang-undangan.

Mengacu pada kondisi pasar dalam negeri Indonesia, industri perbankan dan keuangan syariah tumbuh dengan pesat. Menurut data Direktorat Perbankan Syariah Bank Indonesia 2009, Sepanjang 2008 dan 2009 pemerintah telah menerbitkan Surat Berharga Syariah Negara (SBSN) sebanyak 4 kali dengan total akumulatif mencapai Rp 19,8 triliun. Awal tahun 2009 pemerintah menerbitkan Obligasi syariah (sukuk) ritel seri SR-001 dan obligasi syariah (sukuk) global SNI. Untuk penerbitan obligasi syariah (sukuk) global sebesar 650 juta US dolar mengalami over subscribed hingga 7 kali lipatnya atau 4,7 miliar US dolar. Kelebihan permintaan atas obligasi syariah (sukuk) global yang cukup besar ini menjadi sinyal prospek obligasi syariah (sukuk) sebagai alternatif sumber pembiayaan untuk membiayai pembangunan dalam negeri, khususnya pembangunan infrastruktur. Sedangkan penerbitan obligasi syariah (sukuk) korporasi tahun 2009 sebesar Rp 2,070 triliun. Naik 34,94 persen dibandingkan tahun 2008 sebesar Rp 1,534 triliun. (Ali Rama, www.isefid.org).

Salah satu bentuk investasi yang sesuai dengan syariah Islam adalah pada efek syariah. Efek syariah tersebut mencakup saham syariah, obligasi syariah, reksadana syariah, kontrak investasi kolektif efek beragun asset syariah, dan surat berharga lainnya yang sesuai dengan prinsip Syariah. Dari konsep kelembagaan dalam ekonomi yang 
berkembang saat ini salah satunya adalah sukuk. Sukuk dipandang sebagai alternatif yang lebih baik dari pada berutang karena antara lain mengandung unsur kerja sama investasi, berbagi resiko dan keterlibatan aset (proyek-riil) yang juga mendasari penerbitan sukuk. Indonesia sebagai salah satu negara dengan tingkat kekuatan fiskal yang rendah sangat membutuhkan sukuk negara untuk pembiayaan defisit anggaran.

Dengan pendekatan matematik dapat disimpulkan bahwa perekonomian yang menerbitkan sukuk untuk pembiayaan defisit anggaran maupun proyek-proyek pemerintah akan memiliki potensi peningkatan fiscal sustainability dalam jangka panjang. Hal ini dikarenakan pembiayaan dengan instrument sukuk didasarkan pada underlying asset yang berimplikasi pada aktivitas ekonomi riil dan terbebas dari aspek spekulasi. Terkait dengan upaya pengembangan pasar modal syariah, hingga saat ini terdapat beberapa fatwa DSN-MUI yang berkaitan dengan industri pasar modal, diantaranya adalah Fatwa No. 5 tahun 2000 tentang Jual Beli Saham; No.20 tahun 2000 tentang Pedoman Pelaksanaan Investasi untuk Reksa Dana Syariah; No. 32 tahun 2002 tentang Obligasi Syariah; No. 33 tahun 2002 tentang Obligasi Syariah Mudharabah; No. 40 tahun 2003 tentang Pasar Modal dan Pedoman Umum Penerapan Prinsip Syariah di Bidang Pasar Modal; dan No. 41 tahun 2004 tentang Obligasi Syariah Ijarah.

Sukuk merupakan salah satu alternatif untuk dapat memperoleh dana segar dari negara-negara Timur Tengah, yang merupakan negaranegara kaya penghasil minyak yang tergabung dalam Gulf Corporation Council (GCC) karena sesuai dengan prinsip-prinsip syariah. Sukuk kian menarik karena mampu merangkul investor syariah yang selama ini terpinggirkan tanpa membatasi diri terhadap para investor obligasi konvensional. Selain itu terpukulnya sistem ekonomi konvensional yang selama ini sering terpukul karena bubble yang terjadi membuat sukuk sebagai salah satu instrumen ekonomi syariah makin dilirik, bahkan oleh investor obligasi konvensional sekalipun(Nanda Sitepu, 2010). Sukuk negara ritel sebagaimana telah disebutkan di atas, menjadi alasan utama dijadikan sebagai lahan investasi para investor kecil karena nilai minimal pembelian relatif kecil yakni sebesar Rp. 5.000.000,-. Keuntungan ini di- 
tambah dengan hasil sewa dari produk ini yang didapatkan pertahunnya dari pembelian sukuk ini yaitu pada awal terbitnya sebesar $12 \%$, lebih tinggi dari obligasi ritel Indonesia yang besar keuntungan bunganya hanya $10 \%$ pertahun. Di Indonesia, pemerintah resmi menerbitkan sukuk negara ritel pada 25 Februari 2009 untuk mendukung APBN 2009. Jenis akad sukuk negara ritel yang akan diterbitkan adalah ijarah sale and lease back dengan underlying assets berupa barang milik negara berupa tanah dan/atau bangunan yang saat ini sedang digunakan oleh Depkeu.

Obligasi syariah ini diterbitkan selain untuk menutupi kebutuhan modal kerja juga bisa digunakan untuk pembangunan infrastruktur baik oleh perusahaan atau pemerintah. Dengan demikian, obligasi syariah bisa dimanfaatkan sebagai alternatif sumber pendanaan bagi perusahaan. Obligasi syariah sebagai sumber pendanaan bagi perusahaan lebih kompetitif dibandingkan dengan obligasi konvensional. Tetapi kecenderungan investor memang berbeda-beda karena sudut pandang yang digunakan untuk menganalisis dan memprediksi investasi yang akan mereka lakukan pun berbeda. Walaupun kepedulian investor dan perusahaan makin berkembang pada alternatif investasi dan pendanaan bagi mereka, seperti adanya obligasi syariah (sukuk) ini, tetapi belum semua perusahaan menggunakan obligasi syariah (sukuk) sebagai instrumen pendanaannya selain saham yang memang masih dominan hingga saat ini. Beberapa keuntungan sukuk dibanding dengan produk lainnya yang mempengaruhi minat investor dalam membeli sukuk ini adalah tergambar dalam tabel perbandingan berikut :

Tabel 1: Perbandingan Sukuk dan Obligasi

\begin{tabular}{|l|l|l|}
\hline \multicolumn{1}{|c|}{ Deskripsi } & \multicolumn{1}{c|}{ Sukuk } & \multicolumn{1}{c|}{ Obligasi } \\
\hline Penerbit & Pemerintah dan korporasi & Pemerintah dan korporasi \\
\hline Sifat instrumen & $\begin{array}{l}\text { Sertifikat kepemilikan/ } \\
\text { penyertaan atas suatu asset/ } \\
\text { investasi }\end{array}$ & $\begin{array}{l}\text { Instrumen pengakuan } \\
\text { hutang (surat hutang) }\end{array}$ \\
\hline Penghasilan & Imbalan/bagi hasil/margin & Bunga/kupon/capital gain \\
\hline Jangka waktu & Pendek-menengah & Menengah - jangka panjang \\
\hline
\end{tabular}




\begin{tabular}{|l|l|l|}
\hline Harga & Market price & Market price \\
\hline Underlying & Perlu & Tidak Perlu \\
\hline Jenis investor & Syariah dan konvensional & Konvensional \\
\hline Pihak yang terkait & Obligor, SPV, investor, trustee & Obligor / issuer, investor \\
\hline Penggunaan dana & Harus sesuai syariah & Bebas \\
\hline
\end{tabular}

Sumber: Direktorat Kebijkan Pembiayaan Syariah, 2008

Beberapa keuntungan sukuk dibandingkan dengan produk lainnya yang mempengaruhi minat para investor dalam membeli sukuk seperti pada tabel berikut ini:

Tabel 2: Perbandingan Instrumen Investasi

\begin{tabular}{|l|l|l|l|l|}
\hline \multicolumn{1}{|c|}{ Perbandingan } & \multicolumn{1}{|c|}{ Saham } & \multicolumn{1}{c|}{$\begin{array}{c}\text { Reksadana } \\
\text { Terproteksi }\end{array}$} & \multicolumn{1}{c|}{ Deposito } & \multicolumn{1}{c|}{$\begin{array}{c}\text { Sukuk } \\
\text { Negara Ritel }\end{array}$} \\
\hline $\begin{array}{l}\text { Bentuk return } \\
\text { investasi }\end{array}$ & Deviden & Kupon obligasi & Bunga & Imbal hasil \\
\hline Kepastian return & Tidak pasti & $\begin{array}{l}\text { Tergantung } \\
\text { harga obligasi }\end{array}$ & $\begin{array}{l}\text { Tergantung } \\
\text { suku bunga }\end{array}$ & Pasti \\
\hline $\begin{array}{l}\text { Besaran return } \\
\text { investasi }\end{array}$ & Tidak pasti & $9 \%-12 \%$ & $8 \%-13 \%$ & $12 \%$ \\
\hline $\begin{array}{l}\text { Pembagian return } \\
\text { investasi }\end{array}$ & Tidak pasti & Pasti & Tiga bulanan & Bulanan \\
\hline Minimal investasi & Rp. 10 juta & Rp. 1 juta & Rp. 1 juta & Rp. 5 juta \\
\hline $\begin{array}{l}\text { Potensi selisih } \\
\text { harga di pasar } \\
\text { sekunder }\end{array}$ & Ada & $\begin{array}{l}\text { Tidak diper- } \\
\text { dagangkan }\end{array}$ & $\begin{array}{l}\text { Tidak diper- } \\
\text { dagangkan }\end{array}$ & Ada \\
\hline Masa jatuh tempo & Tidak Ada & Ada & Ada & Ada \\
\hline $\begin{array}{l}\text { Jaminan } \\
\text { pemerintah }\end{array}$ & Tidak Ada & Tidak Ada & $\begin{array}{l}\text { Maksimal } 2 \\
\text { Milyar }\end{array}$ & Ada \\
\hline
\end{tabular}

\section{Sumber: Wafa, 2010}

Semakin berkembangnya volume SBSN menandakan bahwa SBSN masih menjadi instrumen investasi yang menarik di pasar, terutama pasar keuangan syariah. Hal ini juga ditandai oleh semakin meningkatnya transaksi 
SBSN di pasar sekunder. Selama 2012, total volume transaksi SBSN adalah sebesar Rp98,4 triliun (RRH Rp400,1 miliar), meningkat sekitar 126,28\% dari volume transaksi tahun sebelumnya yang sebesar Rp43,5 triliun. Sama halnya dengan frekuensi transaksi SBSN pada tahun 2012 sebanyak 17.050 kali (RRH 69 kali) yang meningkat sekitar 44,47\% dari tahun sebelumnya yang sebanyak 11.802 kali. Perkembangan pasar SBSN juga terlihat dari turn over ratio transaksi. Turn over ratio merupakan tolak ukur likuiditas suatu obligasi yang menunjukkan tingkat perdagangan di pasar sekunder relatif terhadap jumlah obligasi yang beredar. Sehingga semakin tinggi nilai turnover ratio SBSN menandakan pasar sekunder SBSN yang semakin aktif.

\section{Plus Minus Investasi di Sukuk}

Islam sangat menganjurkan umatnya untuk melakukan aktifitas ekonomi (mu'amalah) dengan cara yang benar dan baik, serta melarang penimbunan barang, atau membiarkan harta (uang) tidak produktif, sehingga aktifitas ekonomi yang dilakukan dapat meningkatkan ekonomi umat. Dengan kata lain, investasi itu penting dilakukan oleh umat Islam. Beberapa tahun terakhir memang terlihat trend dari masyarakat muslim untuk lebih peduli pada peluang investasi, terlebih yang sesuai dengan Syariah. Investasi adalah suatu kegiatan seseorang dalam mengfungsikan kekayaan untuk memperoleh pendapatan atau keuntungan lainnya dalam jangka panjang.

Pengertian lain menyebutkan investasi bisa diartikan sebagai suatu tindakan untuk mengembangkan nilai aset yang kita punya. Investasi dapat dilakukan dalam sektor riil maupun keuangan. Investasi dalam sukuk negara ritel berarti adalah investasi di sektor keuangan. Sukuk Negara Ritel merupakan kesempatan emas bagi individu rakyat Indonesia untuk ikut berpartisipasi menyukseskan pembangunan negara. Untuk masyarakat muslim, ini merupakan instrumen investasi yang sangat aman dan sesuai syariah yang dikeluarkan negara khusus untuk individu rakyat Indonesia. Selain ikut berpartisipasi dalam pembangunan negara, investor juga akan mendapatkan imbalan yang sangat menarik yakni dengan kupon 12\% untuk pembelian pada tahun 2009, semoga pada tahun 2011 tidak jauh 
berbeda. Secara spesifik, keuntungan berinvestasi pada Sukuk Negara Ritel yang berkode SR adalah sebagai berikut:

1. Memberikan penghasilan berupa imbalan atau nisbah bagi hasil yang kompetitif, investor memperoleh imbalan yang lebih tinggi dari rata-rata tingkat bunga deposito bank BUMN.

2. Pembayaran imbalan dan Nilai Nominal sampai dengan sukuk jatuh tempo dijamin oleh pemerintah. Imbalan bersifat tetap dan dibayarkan setiap bulan sampai dengan jatuh tempo.

3. Dapat diperjual-belikan di pasar sekunder sesuai dengan harga pasar, sehingga investor berpotensi mendapatkan capital gain di pasar sekunder.

4. Investasi yang aman, karena pembayaran imbalan dan nilai nominalnya dijamin oleh Undang-Undang.

5. Investasi yang menentramkan, karena tidak bertentangan dengan prinsip-prinsip syariah seperti riba (usury), gharar (uncertainty), dan maysir (gambling).

6. Prosedur pembelian dan penjualan yang mudah dan transparan. Cara berinvestasi dalam sukuk negara ritel itu sangat mudah dan transparan.

Bagi calon pembeli, caranya pemesanan pembelian sukuk negara ritel adalah sebagai berikut:

1. Menghubungi agen penjual yang melayani pemesanan pembelian Sukuk Negara Ritel.

2. Membuka rekening dana (jika diperlukan) pada salah satu bank umum dan rekening surat berharga (jika diperlukan) pada salah satu bank kustodian anggota subregistry atau partisipan/nasabah subregistry.

3. Menyetor dana sesuai jumlah pembelian ke rekening "Sukuk Negara Ritel" pada bank yang ditunjuk oleh agen penjual. Ini dilakukan dilakukan oleh agen penjual, investor tinggal menunjukkan dana yang akan digunakan untuk memesan Sukuk Negara Ritel.

4. Mengisi dan menandatangani formulir pemesanan serta melam- 
pirkan fotokopi KTP dan foto kopi bukti transfer dana.

5. Menerima tanda terima bukti pemesanan pembelian dari agen penjual.

6. Menunggu hasil keputusan penjatahan yang ditetapkan pemerintah untuk mengetahui jumlah sukuk negara ritel yang dimenangkan.

7. Menerima konfirmasi kepemilikan sukuk negara ritel sesuai dengan jumlah pemesanan pembelian yang dimenangkan.

Di balik kelebihan sukuk ada sejumlah resiko yang perlu diperhatikan. Resiko sukuk dapat dibagi menjadi risiko pasar (market risk), risiko operasional (operational risk) dan risiko ketentuan syariah (shariah compliance risk). Market risk terdiri dari risiko suku bunga (interest rate risk atau rate of return risk) dan resiko nilai tukar (foreign exchange rate risk) dapat di jelaskan berikut.

1. Resiko tingkat bunga, sukuk ijarah, Istisna, salam dan yang didasarkan atas fixed rate menanggung akibat dari naik turunnya tingkat suku bunga. Kenaikan suku bunga menjadikan tingkat nilai sukuk kurang diminati oleh investor.

2. Resiko nilai tukar (foreign exchange rate) dapat dijelaskan bahwa sertifikat sukuk didenominasi di dalam Dolar Amerika (US\$) sehingga naik turunnya nilai rupiah terhadap dolar akan menjadikan nilai pembayaran terhadap investor akan berubah dari nilai awal. Seperti turunnya nilai rupiah terhadap dolar menjadikan beban pembayaran cicilan menjadi semakin besar kepada investor.

3. Resiko operasional sukuk (operastional risk) terdiri dari resiko kegagalan pembayaran (default risk), resiko pembayaran kupon (coupon payment risk), resiko pelunasan asset (asset redemption risk), resiko SPV (SPV specific risk), resiko investor (investor specific risks), resiko berhubungan dengan aset (risk related to the asset).

4. Keterbatasan barang milik negara yang dapat dijadikan underlying asset. Sukuk merupakan sertifikat pembiayaan yang didasarkan atas jaminan aset rill yang besarnya didasarkan atas aset yang marketable di pasar keuangan global. Semakin banyak aset yang 
sesuai dengan standar yang ditentukan semakin besar bagi negara untuk mendapatkan pembiayaan dari investor internasional. Ini menunjukkan bahwa besarnya dana yang diperoleh di dasarkan besar aset yang kita miliki sehingga perlu juga kita memperbaiki sarana dan prasarana yang mendukung bagi persediaan aset yang layak jual.

\section{Kesimpulan}

Perkembangan sukuk korporasi di Indonesia dilihat dari emisi maupun jumlah penerbitan terbilang sangat lambat. Terdapat banyak tantangan dalam pengembangan sukuk secara umum, mulai dari aspek syariah, kerangka hukum, regulasi, pasar, sampai kompleksitas produk. Hal tersebut merupakan sebuah kewajaran karena sukuk dapat dikategorikan produk baru yang diintegrasikan pada pasar keuangan konvensional yang telah mapan.

Permasalahan utama dalam pengembangan sukuk korporasi terletak pada (1) ketidakjelasan pajak (regulasi); (2) minimnya sumber daya manusia profesional (pelaku pasar); (3) minim pemahaman pelaku modal (pelaku pasar). Solusi yang ditawarkan terhadap permasalahan tersebut anatar lain melalui revisi aturan pajak atau penghapusan pajak ganda dan penerbitan sukuk negara dapat diimplementasikan secepatnya dan merupakan solusi jangka pendek. Sementara sosialisasi edukasi dan penyediaan sumber daya yang profesional merupakan solusi jangka panjang yang harus dilakukan secara simultan. Hal ini sejalan dengan kebijakan pemerintah dalam mengembangkan ekonomi syariah di Indonesia secara umum, yaitu bottom up approach. Membangun basis fundamental yang kuat di masyarakat, kemudian membuat regulasi dan kebijakn-kebijakan yang dianggap perlu untuk mengakomodasi pasar secara bertahap.

Peningkatan inovasi dan kualitas produk sukuk. Hal ini sangat penting agar struktur sukuk yang ada dapat menarik minat investor, sekaligus dapat menggerakkan sektor riil. Untuk itu dibutuhkan pening- 
katan kualitas SDM yang ada. SDM tersebut diharapkan memiliki kapasitas dalam melakukan sukuk structuring, dan memiliki cara berpikir yang berbeda. Maksudnya, mindset tentang sukuk harus berbeda dengan mindset tentang obligasi konvensional (Surat Utang Negara konvensional).

Edukasi dan sosialisasi publik. Ini adalah hal yang sangat fundamental mengingat awareness publik yang masih sangat rendah terhadap produk-produk di pasar modal syariah, termasuk sukuk. Peningkatan eskalasi kampanye publik ini diharapkan dapat mendorong perkembangan minat mereka untuk terlibat berinvestasi pada produk sukuk secara langsung. Jika keempat hal ini dapat dilaksanakan dengan baik, maka peran SBSN atau sukuk negara dalam menggerakkan perekonomian nasional akan semakin kuat. Wallahu a'lam.

\section{Daftar Pustaka}

Achsein, I.H. 2003. Investasi Syariah di Pasar Modal: Menggagas Konsep dan Praktek Manajemen Portofolio Syariah. Cetakan. Kedua. Jakarta: Gramedia Pustaka Utama.

Ali Rama. Prospek dan Potensi Sukuk Cukup Menjanjikan. Masjid Kita Ekonomi Syariah.

Bapepam-LK (Badan Pengawas Pasar Modal \& Lembaga Keuangan) . 2011. Laporan Keuangan. Annual Report. Kementerian Keuangan RI.

Beik, I. S. 2011. Optimalisasi SBSN dalam Pembangunan Ekonomi Nasional. Makalah disampaikan pada Seminar Sukuk Negara Goes to Campus, Bogor, 29 April.

Dewan Syariah Nasional MUI dan Bank Indonesia. 2003. Himpunan Fatwa Dewan Syariah Nasional. Edisi Kedua, Jakarta: Intermasa.

Direktorat Kebijakan Pembiayaan Syariah. 2008. Mengenal Instrumen Investasi dan Pembiayaan Berbasis Syariah. Jakarta: Departemen Keuangan.

Islamic Finance Information System. (2010). Database.

Kamal Zubair (2008) Instrumen Investasi Pasar Modal (Analisis Perbandingan Obligasi dan Sukuk), International Seminar and 
Symposiumon Implementation of Islamic Economics To Positive Economics in The World as Alternative of Conventional Economics System:Toward Development in The New Era of The Holistic Economics, (Surabaya: Unair, 1-2 Agustus 2008), p.23.

Kementerian Keuangan. 2011. Laporan Keuangan Pemerintah Pusat.

Nanda, Sitepu (2010), “Sukuk; Definisi, Kondisi, dan Potensi?", dikutip dari http://www.vibiznews.com.

Nasution, Mustafa Edwin et al. 2006. Pengenalan Ekslusif Ekonomi Islam. Cetakan Pertama. Jakarta: Kencana, hlm.304.

Nur Kholis. Sukuk Instrume Investasi yang halal dan Menjajikan. La_ Riba. Jurnal Ekonomi Islam. Volume IV, No.2 Desember.

Peraturan Menteri Keuangan No. 218 Tahun 2008 Tentang Penerbitan dan Penjualan Surat Berharga Syariah Negara Ritel Di Pasar Perdana Dalam Negeri.

Tariq, Ali Arsalan.2004. Managing Financial Risk of Sukuk Structures. Tesis S2 yang dipublikasikan.

UU No.19 Tahun 2008 tentang Surat Berharga Syariah Negara.

Wafa, Muhammad Agus Khoirul.2010.Analisa Faktor-faktor yang Mempengaruhi Tingkat Permintaan Sukuk Ritel Periode Maret 2009 -Juni 2010. La Riba.Jurnal Ekonomi Islam.

Yasni, M. Gunawan, 2009.“Sukuk Ritel Yang Paling Bersinar”, Majalah Sharing.

\section{Internet:}

http://nasional.kompas.com/read/2009/01/07/13104029/Sukuk.Ritel. Terbit.25.Februari, website kompas tanggal 7 Januari 2009, diakses pada tanggal 5 Maret 2013. 